\title{
Suppression of the First Cleavage and Cytogenetic Studies on the Gynogenetic Loach
}

\author{
Makoto Suwa, ${ }^{* 1}$ Katsutoshi Arai, ${ }^{* 1,2, \dagger}$ and Ryo Suzuki*1,2 \\ *' Graduate School of Biosphere Sciences, Hiroshima University, Kagamiyama, Higashi-hiroshima, Hiroshima 724, Japan \\ ${ }^{* 2}$ Faculty of Applied Biological Science, Hiroshima University, Kagamiyama, Higashi-hiroshima, Hiroshima 724, Japan
}

(Received December 24, 1993)

\begin{abstract}
Optimum conditions of hydrostatic pressure were examined for induction of two types of gynogenetic diploids (meiotic and mitotic) in the loach. Hydrostatic pressure treatment of 700 and $800 \mathrm{~kg} / \mathrm{cm}^{2}$ for 1 min duration gave the best yield of normal fry when the treatment began $5 \mathrm{~min}$ after fertilization by inhibiting the second meiosis of fertilized eggs. For mitotic gynogenesis by suppression of the first cleavage, the optimum time of application of the pressure $\left(800 \mathrm{~kg} / \mathrm{cm}^{2}, 1 \mathrm{~min}\right.$ duration) was determined to be 30 or $35 \mathrm{~min}$ after fertilization.

In the early stage of embryos of mitotic gynogens, various aneuploids with cytogenetic aberrations were detected, in addition to induced diploids and miss-induced haploids. These were considered the major factors responsible for poor development and survival. All hatched fry of the mitotic gynogens were determined as diploid or near-diploid even in the case of severely deformed fry.

Homozygosity of the mitotic gynogens was confirmed by isozyme analysis at the protein locus $M P I^{*}$ which has a very high rate of gene-centromere recombination.
\end{abstract}

Key words: gynogenesis, loach, chromosome aberration, inhibition of the first cleavage, gene-centromere recombination rate, isozyme

Conventional sib-mating has not been adopted in fish except for medaka Oryzias latipes ${ }^{11}$ as a method for establishment of inbred line because of the long generation time in most fish. As a rapid procedure for obtaining inbred lines, clonal production should be possible by gynogenetic reproduction through two successive generations. This would entail the induction of completely homozygous diploids by suppressing the first cleavage of gynogenetically developing eggs (mitotic gynogenesis) in the first generation, and the production of genetically identical gynogenetic diploids from the first generation broodfish by retaining the second polar body (meiotic gynogenesis or polar-body gynogenesis) in the second generation. Realization of clonal fish was achieved first in laboratory-reared zebra fish Brachydanio rerio ${ }^{21}$ and medaka Oryzias latipes, ${ }^{3)}$ then in commercially important species; carp Cyprinus carpio ${ }^{4)}$ ayu Plecoglossus altivelis, ${ }^{5)}$ and plaice Paralichthys olivaceus, ${ }^{6)}$ but it is still quite difficult to produce inbred lines in most fish species because of the extremely low survival rates of mitotic gynogens in the process from the induction to the maturation. ${ }^{4}$. The success of a few examples produced by induction of mitotic gynogenesis has been discussed from the perspective of the influence of recessive, deleterious genes as well as the mechanical injury to chromosomes by physical treatments, ${ }^{3,4)}$ but many difficulties still remain to be solved.

In this study, we attempted to determine the optimum conditions of pressure treatments for diploidizing gynogenetically activated eggs in the loach Misgurnus anguillicaudatus. The genetic inactivation of spermatozoa and optimum cold-shocking conditions to produce meiotic gynogens have been well established for this species. ${ }^{7)}$ To ex- amine the cytogenetic factors responsible for low survival in mitotic gynogenesis, chromosomes were observed in embryos and fry developed from eggs subjected to hydrostatic pressure. Complete homozygosity of the mitotic gynogens was demonstrated by homozygous genotypes in an isozyme locus with a very high rate of gene-centromere recombination.

\section{Materials and Methods}

The source of female loach and a summary of the experimental conditions used to optimize hydrostatic pressure treatments are shown in Table 1. The procedures for artificial ovulation, fertilization and ultraviolet ray (UV) irradiation to inactivate the spermatozoa were as described in Suzuki et $a l^{7)}$ The dose of UV rays was $6750-9000 \mathrm{erg} / \mathrm{mm}^{2}$. Spermatozoa from the minnow Gnathopogon elongatus elongatus, carp Cyprinus carpio, and goldfish Carrasius auratus were used to verify gynogenesis. All hybrids between female loach and males of the three species were abnormal and inviable. ${ }^{8)}$ In a few cases ( $\$ 2019$ and 2024), variant loach (orange phenotype) which were homozygous for a recessive demelanogenesis gene ${ }^{7)}$ were used as females for verifying gynogenesis.

After fertilization with irradiated spermatozoa, eggs were incubated in $25^{\circ} \mathrm{C}$ water until the hydrostatic pressure treatment. Gynogenetically activated eggs were placed on a glass $(25 \times 200 \mathrm{~mm})$ and subjected to hydrostatic pressure in a cylinder of a French press. In the first experiment we examined the optimum dose of hydrostatic pressure to inhibit the release of the second polar body. We varied the pressure between 300 and $800 \mathrm{~kg} / \mathrm{cm}^{2}$ and the duration of treatment between 1 and $6 \mathrm{~min}$. Treatment commenced $5 \mathrm{~min}$ after fertilization.

With a fixed dose of hydrostatic pressure $\left(800 \mathrm{~kg} / \mathrm{cm}^{2}, 1 \mathrm{~min}\right)$, the optimum starting times of pressure treatment to suppress the first cleavage were examined in the period between 20 and $50 \mathrm{~min}$ after fertilization (Table 1). Two controls were used: (UC) Untreated control; eggs fertilized with non-irradiated spermatozoa of loach but not treated with hydrostatic pressure and (GC) gynogenetic control; eggs fertilized with irradiated spermatozoa of loach, minnow, carp, or goldfish but not treated with

\footnotetext{
† To whom all correspondence should be mailed.
} 
Table 1. Female loach used, origin of spermatozoa, and conditions of hydrostatic pressure treatments in the present study

\begin{tabular}{|c|c|c|c|c|c|c|}
\hline Female & Locality & $\begin{array}{l}\text { Wild }(W) \text { or } \\
\text { Culture }(C)\end{array}$ & Spermatozoa & $\begin{array}{l}\text { Starting time of } \\
\text { treatment (min) }\end{array}$ & $\begin{array}{l}\text { Pressure level } \\
\left(\mathrm{kg} / \mathrm{cm}^{2}\right)\end{array}$ & $\begin{array}{l}\text { Duration of } \\
\text { treatment (min) }\end{array}$ \\
\hline 1037 & Tottori & $\mathrm{C}$ & Loach & 5 & $300-800$ & $1-6$ \\
\hline \multirow[t]{2}{*}{1043} & Tottori & $\mathrm{C}$ & Loach & 5 & 700 & 1 \\
\hline & & & & $20-50$ & 800 & 1 \\
\hline \multirow[t]{2}{*}{1049} & Tottori & $\mathrm{C}$ & Loach & 5 & 700 & 1 \\
\hline & & & & $20-50$ & 800 & 1 \\
\hline 1052 & Tottori & $\mathrm{C}$ & Loach & $25-35$ & 800 & 1 \\
\hline \multirow[t]{2}{*}{2001} & Mie & $\mathrm{C}$ & Minnow & 5 & 700 & 1 \\
\hline & & & & $25-35$ & 800 & 1 \\
\hline \multirow[t]{2}{*}{2002} & Hiroshima Univ. ${ }^{* 1}$ & $\mathrm{C}$ & Minnow & 5 & 700 & 1 \\
\hline & & & & $25-35$ & 800 & 1 \\
\hline $2018 \mathrm{~A}$ & Okayama & W & Carp & $25-35$ & 800 & 1 \\
\hline \multirow[t]{2}{*}{$2018 \mathrm{~B}$} & Okayama*2 & W & Goldfish & 5 & 700 & 1 \\
\hline & & & & $30-35$ & 800 & 1 \\
\hline 2019 & Saitama*3 & $\mathrm{C}$ & Loach & 2540 & 800 & 1 \\
\hline 2024 & Saitama*3 & $\mathrm{C}$ & Loach & $30-40$ & 800 & 1 \\
\hline \multirow[t]{2}{*}{2041} & Hiroshima Univ.*4 & $\mathrm{C}$ & Minnow & 5 & 700 & 1 \\
\hline & & & & 35 & 800 & 1 \\
\hline 2058 & Hiroshima & $\mathrm{C}$ & Goldfish & $25-40$ & 800 & 1 \\
\hline
\end{tabular}

*1 Originated from artificial seed produced in 1990.

*2. The same female as $\# 2018 \mathrm{~A}$.

*3 Variant loach with orange phenotype.

*4 The meiotic gynogen induced from $\$ 1037$ female in 1991

hydrostatic pressure. After the treatment, each experimental group was reared separately in a shallow container $(250 \times 200 \times 30 \mathrm{~mm})$ with fresh water at $20^{\circ} \mathrm{C}$. The proportion of eggs that develop (Develop \%) was observed at about $24 \mathrm{~h}$ after fertilization. The proportion of eggs that hatched (Hatch \%) and the proportion that were normal (Normal \%) relative to the initial number of fertilized eggs were recorded.

The procedures for chromosome preparation in embryonic cells; dechorionization of eggs, colchicine treatment, hypotonic treatment, fixation, mincing of samples and staining of chromosome slides were as described in Arai et al., ${ }^{93}$ and those in the fry cells were the same as the methods developed by Ojima et al. ${ }^{109}$ Before chromosome preparation, fry specimens were classified into three groups based on the external appearance; normal, slightly deformed and severely deformed. Two day-old fry were minced on the edge of a microtube $(2 \mathrm{~m} l)$ and suspended in $1 \mathrm{~m} l$ of $0.1 \%$ trypsin solution with $0.01 \% 2 \mathrm{Na} \cdot \mathrm{EDTA}^{* 3}$ dissolved in $\operatorname{PBS}(-),{ }^{* 4}$ a small magnetic tip was placed in the tube and the microtube was placed on a magnetic stirrer for $10 \mathrm{~min}$. One $\mathrm{ml}$ of Eagle $\mathrm{MEM}^{* 5}$ with $20 \%$ fetal bovine serum was added to the microtube which was then centrifuged at $1000 \mathrm{rpm}$ for $10 \mathrm{~min}$. The cells obtained were treated with colchicine $(0.1 \mu \mathrm{g} / \mathrm{m} / \mathrm{MEM})$ for $2 \mathrm{~h}$ then immersed in hypotonic solution $(0.065 \mathrm{M} \mathrm{KCl})$ for $20 \mathrm{~min}$, air dried and fixed with Carnoy's ethanol-acetic acid mixture. The slides were stained with $2 \%$ Giemsa solution. Three or more cells were counted in each embryo or fry.

The enzymes analyzed, EC numbers, abbreviations of enzymes, and the buffer systems used for electrophoresis in the present study are shown in Table 2. The nomenclature of enzymes, locus and allele accorded with Shaklee et al $^{13)}$ Muscle tissues from gynogenetic progeny of females \#1037, $1049,2018 \mathrm{~B}$, and 2041 , from untreated control progeny of females $\$ 1037$, 1049 , and 2041 , and from males used to produce control progeny were examined by protein electrophoresis. Gels were made using 14\% starch gel and samples were electrophoresed for 4 to $6 \mathrm{~h}$ at constant voltage in a $4^{\circ} \mathrm{C}$ refrigerator. After electrophoresis, the gel slices ( $1 \mathrm{~mm}$ thickness) were histochemically stained as described by Allendorf et $a l^{143}$ and Aebersold et al. ${ }^{15)}$ with some modifications.

The gene-centromere (GC) recombination rate can be estimated from the proportion of the heterozygous genotype in gynogenetic diploids produced from a heterozygous female by retention of the second polar body ( $y: 0 \leqq y \leqq 1.0$, second division segregation frequency). ${ }^{15-19)}$ In the mitotic gynogens produced from a heterozygous female, only the homozygous genotypes should occur. ${ }^{20.211} \mathrm{~A}$ gene locus located at the
Table 2. Enzymes analyzed and buffer systems used in the present study

\begin{tabular}{|c|c|c|c|}
\hline Enzyme name & $\begin{array}{c}\mathbb{E C} \\
\text { number }\end{array}$ & $\begin{array}{c}\text { Enzyme } \\
\text { abbreviation }\end{array}$ & $\begin{array}{l}\text { Buffer } \\
\text { system }\end{array}$ \\
\hline Aspartate aminotransferase & 2.6 .1 .1 & AAT & $\mathrm{CA} 7.0^{* 1}$ \\
\hline Glycerol-3-phosphate dehydrogenase & 1.1 .1 .8 & G3PDH & CA7.0 \\
\hline Glucose-6-phosphate isomerase & 5.3 .1 .9 & GPI & $\mathrm{TBCL} * 2$ \\
\hline Isocitrate dehydrogenase & $1.1 .1,42$ & IDHP & CA7.0 \\
\hline Lactate dehydrogenase & 1.1 .1 .27 & $\mathrm{LDH}$ & CA7.0 \\
\hline Mannose-6-phosphate isomerase & 5.3 .1 .8 & MPI & CA7.0 \\
\hline Phosphoglucomutase & 5.4 .2 .2 & PGM & CA7.0 \\
\hline
\end{tabular}

*1 Electrode buffer, $0.04 \mathrm{M}$ citric acid adjusted to pH 7.0 with $N$-(3aminopropy)morpholine; gel buffer, 1 in 20 dilution of electrode buffer. ${ }^{11}$

*2 Electrode buffer, lithium hydroxide $0.06 \mathrm{M}$, boric acid $0.3 \mathrm{M}$, DETA2Na $0.01 \mathrm{M}$, adjusted to pH 8.0 ; gel buffer, Tris $0.3 \mathrm{M}$, citric acid $0.05 \mathrm{M}$, add $10 \%$ of the electrode buffer, use 1 in 10 dilution of the gel buffer. ${ }^{21}$

distal portion of chromosomes is a convenient marker for verifying the success of the mitotic gynogenesis as well as for showing complete homozygosity of the gynogens. Because no isozyme gene has been mapped in the loach, we estimated the $\mathrm{G}-\mathrm{C}$ recombination rate of as many isozyme genes as possible by observing the genotypes of a given locus in the meiotic gynogens of the loach. A small number of specimens were then randomly chosen from the mitotic gynogenetic group and analyzed to determine the genotypes of isozyme loci.

\section{Results}

\section{Optimum Dose of Hydrostatic Pressure}

The optimum strength and duration of hydrostatic pressure treatment were examined for a fixed starting time ( $5 \mathrm{~min}$ after fertilization) by observing the survival of gynogenetic individuals (Fig. 1). High frequencies of developing embryos $(82.7 \%)$ and of normal fry $(78.6 \%)$

\footnotetext{
*3 Ethylenediaminetetraacetic acid disodium salt.

*4 Physiological buffered saline, $\mathrm{Ca}, \mathrm{Mg}$-free.

* Minimum essential medium.
} 


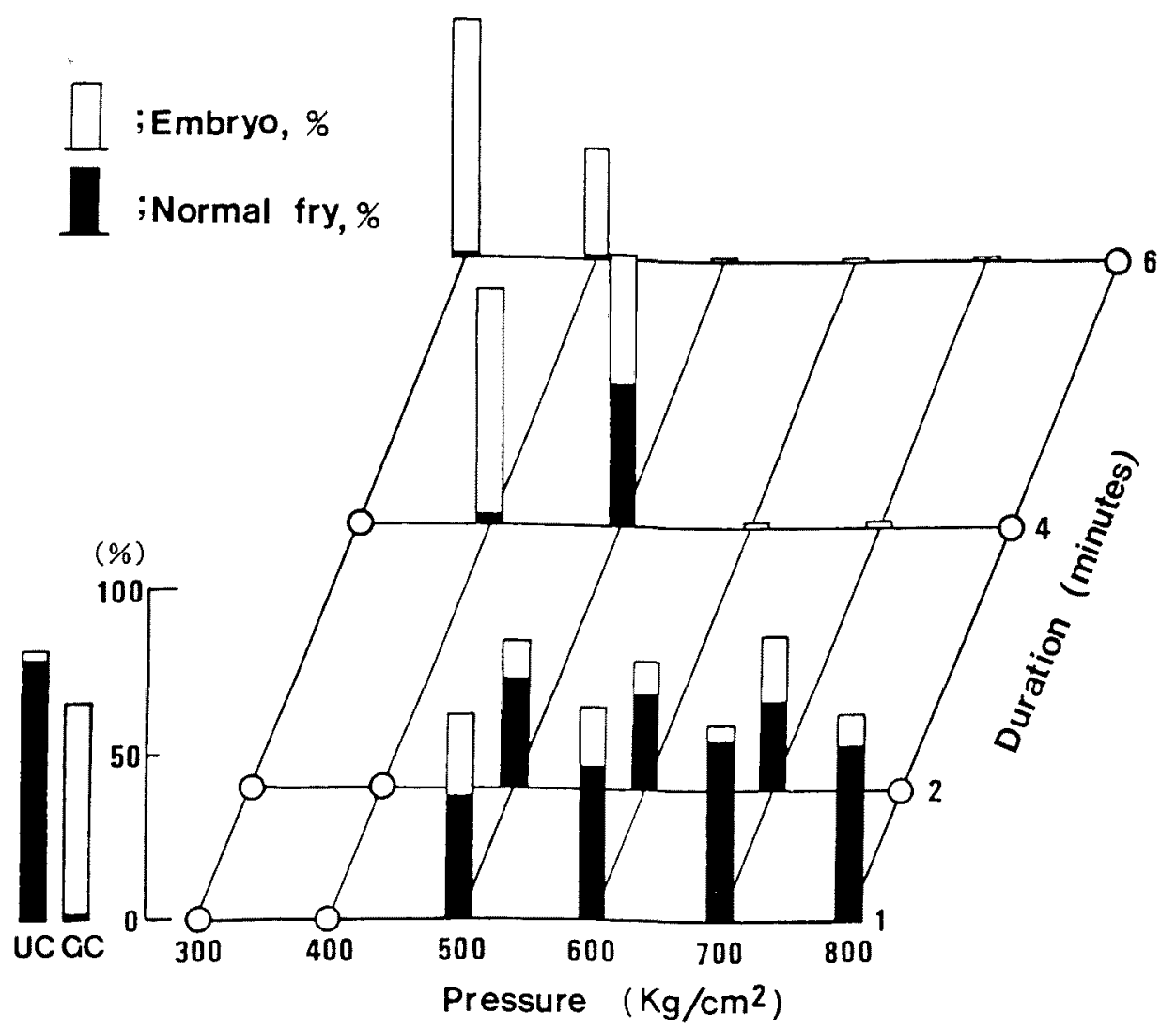

Fig. 1. The effect of different levels $\left(300-800 \mathrm{~kg} / \mathrm{cm}^{2}\right)$ and durations $(1,2,4$, and 6 min) of hydrostatic pressure treatment (applied 5 min after fertilization) on the frequency of developing embryos (Embryo, \%) and normal fry (Normal fry, \%) relative to initial number of eggs fertilized.

IC and GC mean untreated and gynogenetic control, respectively.

were observed in the untreated control which demonstrated a good quality of eggs. Gynogenetic control eggs (GC) fertilized with irradiated spermatozoa without pressure treatment had a relatively high rate of developing embryos, but most hatched fry were abnormal, revealing haploid syndrome, ${ }^{6)}$ which indicates the success of genetic inactivation of spermatozoa. In eggs treated with $700 \mathrm{~kg} /$ $\mathrm{cm}^{2}$ pressure for $1 \mathrm{~min}$, the rate of normal fry was satisfactory $(55.2 \%)$. The pressure treatment with $800 \mathrm{~kg} / \mathrm{cm}^{2}$ for $1 \mathrm{~min}$ gave a similar rate of normal fry $(53.8 \%)$. Relatively high rates of normal fry were also observed in the eggs subjected to $500 \mathrm{~kg} / \mathrm{cm}^{2}$ for 1 to $4 \mathrm{~min}(46.5$ $37.1 \%$ ). In contrast, pressures higher than $600 \mathrm{~kg} / \mathrm{cm}^{2}$ for $4 \mathrm{~min}$ or $500 \mathrm{~kg} / \mathrm{cm}^{2}$ for $6 \mathrm{~min}$ arrested the development in the early embryonic stages. In eggs subjected to low doses $\left(400 \mathrm{~kg} / \mathrm{cm}^{2}\right.$ for $4 \mathrm{~min}$ and $300 \mathrm{~kg} / \mathrm{cm}^{2}$ for $\left.6 \mathrm{~min}\right)$, large number of embryos developed, but only a few normal fry resulted. The normal fry from pressure-treated eggs were presumed to be diploids, so the optimum dose of hydrostatic pressure for diploidization of gynogenetic genome was a treatment with 700 or $800 \mathrm{~kg} / \mathrm{cm}^{2}$ for $1 \mathrm{~min}$.

\section{Optimum Time to Start Pressure Treatment}

Eleven trials using ten females were conducted to determine the optimum starting time for pressure treatment to inhibit the first mitosis (Table 3). Untreated controls produced 55.6 to $86.8 \%$ of developing embryos and 40.6 to $67.5 \%$ of normal fry, indicating fairly good quality of eggs. In gynogenetic controls, most fry exhibited haploid syndrome, indicating that spermatozoa were successfully inactivated genetically. However, normal fry with rates less than $2.3 \%$ were seen among the gynogenetic control, these were not contaminated diploids, but gynogenetic diploids which resulted from spontaneous retention of the polar body. We could make this conclusion because the gynogens were verified by using heterospecific spermatozoa ( $\$ 2001$, $2002,2018 \mathrm{~A}, \mathrm{~B})$ or an orange phenotype ( $\$ 2019$ and 2024). Experimental groups subjected to the fixed dose of hydrostatic pressure $\left(700 \mathrm{~kg} / \mathrm{cm}^{2}, 1 \mathrm{~min}\right)$ starting from $5 \mathrm{~min}$ after fertilization demonstrated relatively high rates of developing embryos (46.7-68.5\%), hatching fry (38.6$59.4 \%)$, and normal fry $(31.9-53.0 \%)$, which indicates successful induction of meiotic diploid gynogens under the conditions described previously.

Poor development and hatching were observed in the groups pressure-treated from $20,25,40,45$, and 50 min after fertilization, whereas a relatively high proportion of embryos developed after pressure shock applied 30 or 35 min after fertilization. Normal fry obtained in these treatments are as follows. Female $\$ 2018 \mathrm{~A}$ gave the highest incidence of normal fry $(25.2 \%)$ in the group treated at $35 \mathrm{~min}$ after fertilization. The female $\$ 2018 \mathrm{~B}$ also produced the highest proportion of normal fry $(8.4 \%)$ when the treatment was started $30 \mathrm{~min}$ after fertilization. Female $\# 2041$, a gynogenetic progeny of $\# 1037$ female, yielded $3.6 \%$ normal fry by the treatment starting $35 \mathrm{~min}$ after 
Table 3. The proportion of developing embryos observed $24 \mathrm{~h}$ after fertilization (Develop, \%), hatching fry (Hatch, \%) and normal fry (Normal, \%) relative to eggs

\begin{tabular}{|c|c|c|c|c|c|c|c|c|c|c|c|}
\hline \multirow{2}{*}{$\begin{array}{l}\text { Female } \\
\end{array}$} & & \multirow{2}{*}{$\mathrm{UC}^{* 4}$} & \multirow{2}{*}{$\mathrm{GC}^{* 5}$} & \multicolumn{8}{|c|}{ Starting time of hydrostatic pressure treatment (min) } \\
\hline & & & & 5 & 20 & 25 & 30 & 35 & 40 & 45 & 50 \\
\hline \multirow[t]{4}{*}{1043} & Egg no. & 651 & 647 & 617 & - & 1349 & 1118 & 1027 & 1144 & 669 & 870 \\
\hline & Develop $(\%)^{* 1}$ & 55.6 & 32.1 & 64.5 & - & 0.2 & 65.4 & 75.7 & 10.3 & 10.3 & 52.1 \\
\hline & Hatch $(\%)^{* 2}$ & 51.2 & 29.2 & 58.3 & - & 0.1 & 50.1 & 53.3 & 4.3 & 4.3 & 43.0 \\
\hline & Normal $(\%)^{* 3}$ & 47.9 & 0.3 & 49.8 & - & 0.0 & 0.8 & 0.5 & 0.0 & 0.1 & 0.3 \\
\hline \multirow[t]{4}{*}{1049} & Egg no. & 678 & 626 & 606 & 454 & 432 & 839 & 693 & 773 & 582 & 449 \\
\hline & Develop $(\%)$ & 71.2 & 29.4 & 68.5 & 0.7 & 5.8 & 47.7 & 4.3 & 2.1 & 1.7 & 0.0 \\
\hline & Hatch $(\%)$ & 67.3 & 25.6 & 59.4 & 0.2 & 1.4 & 9.4 & 1.3 & 0.3 & 0.9 & 0.0 \\
\hline & Normal $(\%)$ & 67.3 & 0.0 & 53.0 & 0.0 & 0.0 & 1.8 & 0.0 & 0.0 & 0.0 & 0.0 \\
\hline \multirow[t]{4}{*}{1052} & Egg no. & 216 & 171 & - & - & 271 & 437 & 227 & - & - & - \\
\hline & Develop (\%) & 65.7 & 59.6 & - & - & 2.2 & 79.4 & 15.0 & - & - & - \\
\hline & Hatch $(\%)$ & 65.7 & 52.0 & - & - & 0.7 & 33.4 & 4.4 & - & - & - \\
\hline & Normal $(\%)$ & 60.7 & 0.0 & - & - & 0.0 & 3.9 & 0.9 & - & - & - \\
\hline \multirow[t]{4}{*}{2001} & Egg no. & 517 & 213 & 323 & - & 397 & 482 & 379 & - & - & - \\
\hline & Develop $(\%)$ & 71.2 & 47.9 & 48.6 & - & 4.0 & 0.0 & 15.8 & - & - & - \\
\hline & Hatch $(\%)$ & 68.0 & 36.6 & 40.6 & - & 2.0 & 0.0 & 4.0 & - & - & - \\
\hline & Normal (\%) & 65.4 & 2.3 & 33.1 & - & 0.8 & 0.0 & 1.1 & - & - & - \\
\hline \multirow[t]{4}{*}{2002} & Egg no. & 234 & 178 & 210 & - & 234 & 410 & 352 & - & - & - \\
\hline & Develop $(\%)$ & 86.8 & 34.5 & 47.6 & - & 0.0 & 0.0 & 22.7 & - & - & - \\
\hline & Hatch $(\%)$ & 76.1 & 31.1 & 38.6 & - & 0.0 & 0.0 & 13.4 & - & - & - \\
\hline & Normal $(\%)$ & 67.5 & 2.0 & 31.9 & - & 0.0 & 0.0 & 1.1 & 一 & -- & - \\
\hline \multirow[t]{4}{*}{$2018 \mathrm{~A}$} & Egg no. & - & 921 & - & - & 385 & 525 & 476 & - & - & - \\
\hline & Develop $(\%)$ & - & 58.6 & - & - & 0.5 & 17.1 & 68.3 & - & - & - \\
\hline & Hatch $(\%)$ & - & 49.2 & - & - & 0.0 & 5.0 & 51.1 & - & - & - \\
\hline & Normal $(\%)$ & - & 0.1 & - & $\cdots$ & 0.0 & 2.9 & 25.2 & $\ldots$ & $-\cdots$ & - \\
\hline \multirow[t]{4}{*}{ 2018B } & Egg no. & - & 334 & 455 & - & - & 557 & 977 & - & - & - \\
\hline & Develop ( $\%)$ & - & 56.6 & 60.7 & - & - & 26.2 & 7.8 & - & - & - \\
\hline & Hatch $(\%)$ & - & 41.6 & 55.8 & - & - & 17.1 & 0.9 & 一 & - & - \\
\hline & Normal (\%) & - & 0.6 & 51.6 & - & - & 8.4 & 0.3 & - & - & 一 \\
\hline \multirow[t]{4}{*}{2019} & Egg no. & - & 335 & - & - & 318 & 381 & 504 & 365 & - & - \\
\hline & Develop $(\%)$ & - & 75.2 & - & - & 0.0 & 1.6 & 50.8 & 15.1 & - & - \\
\hline & Hatch $(\%)$ & - & 43.0 & - & - & 0.0 & 0.8 & 6.5 & 0.5 & - & - \\
\hline & Normal $(\%)$ & - & 1.2 & - & - & 0.0 & 0.5 & 0.2 & 0.0 & - & - \\
\hline \multirow[t]{4}{*}{2024} & Egg no. & 2100 & 566 & - & - & - & 977 & 1422 & 1247 & - & - \\
\hline & Develop $(\%)$ & 84.3 & 83.9 & - & - & - & 0.0 & 40.2 & 10.4 & - & - \\
\hline & Hatch $(\%)$ & 41.5 & 56.5 & - & - & - & 0.0 & 1.7 & 0.0 & - & - \\
\hline & Normal $(\%)$ & 40.6 & 0.0 & - & - & - & 0.0 & 0.5 & 0.0 & - & - \\
\hline \multirow[t]{4}{*}{2041} & Egg no. & 516 & - & 570 & - & - & - & 886 & - & - & 一 \\
\hline & Develop (\%) & 64.9 & - & 62.8 & - & - & - & 35.0 & - & - & - \\
\hline & Hatch $(\%)$ & 60.9 & - & 56.1 & - & - & - & 9.8 & - & - & - \\
\hline & Normal $(\%)$ & 58.5 & - & 52.1 & 一 & - & - & 3.6 & - & - & - \\
\hline \multirow[t]{4}{*}{20.58} & Egg no. & - & 349 & - & - & 937 & 771 & 1675 & 1007 & - & - \\
\hline & Develop $(\%)$ & - & 60.2 & - & - & 0.3 & 0.5 & 35.6 & 17.7 & - & - \\
\hline & Hatch $(\%)$ & 一 & 46.1 & - & - & 0.2 & 0.0 & 15.7 & 4.0 & - & - \\
\hline & Normal (\%) & - & 0.0 & - & - & 0.0 & 0.0 & 5.9 & 1.5 & - & - \\
\hline
\end{tabular}

The pressure treatment was applied at various times ( 5 and 20-50 min) after fertilization.

*1 Development of embryo relative to total eggs used, observed about $24 \mathrm{~h}$ after fertilization.

*2 Hatching of fry relative to total eggs used

*3 Normal of hatched fry relative to total eggs used

*4 Untreated control.

*5 Gynogenetic control. 
fertilization. These results demonstrate that mitotic gynogenesis can be induced when a hydrostatic pressure $\left(800 \mathrm{~kg} / \mathrm{cm}^{2}, 1 \mathrm{~min}\right)$ treatment is applied 30 or $35 \mathrm{~min}$ after fertilization with irradiated spermatozoa. Further refinement of the optimum application time of the treatment was not done. A total of 24 fish ( 12 from $\# 2018$ A, 6 from $\# 2018 B$, 3 from $\# 2041$, and 3 from $\$ 2058$ ), which survived in the treated groups subjected to the hydrostatic pressure under the optimum condition for mitotic gynogenesis, were kept for about 6 months after hatching.

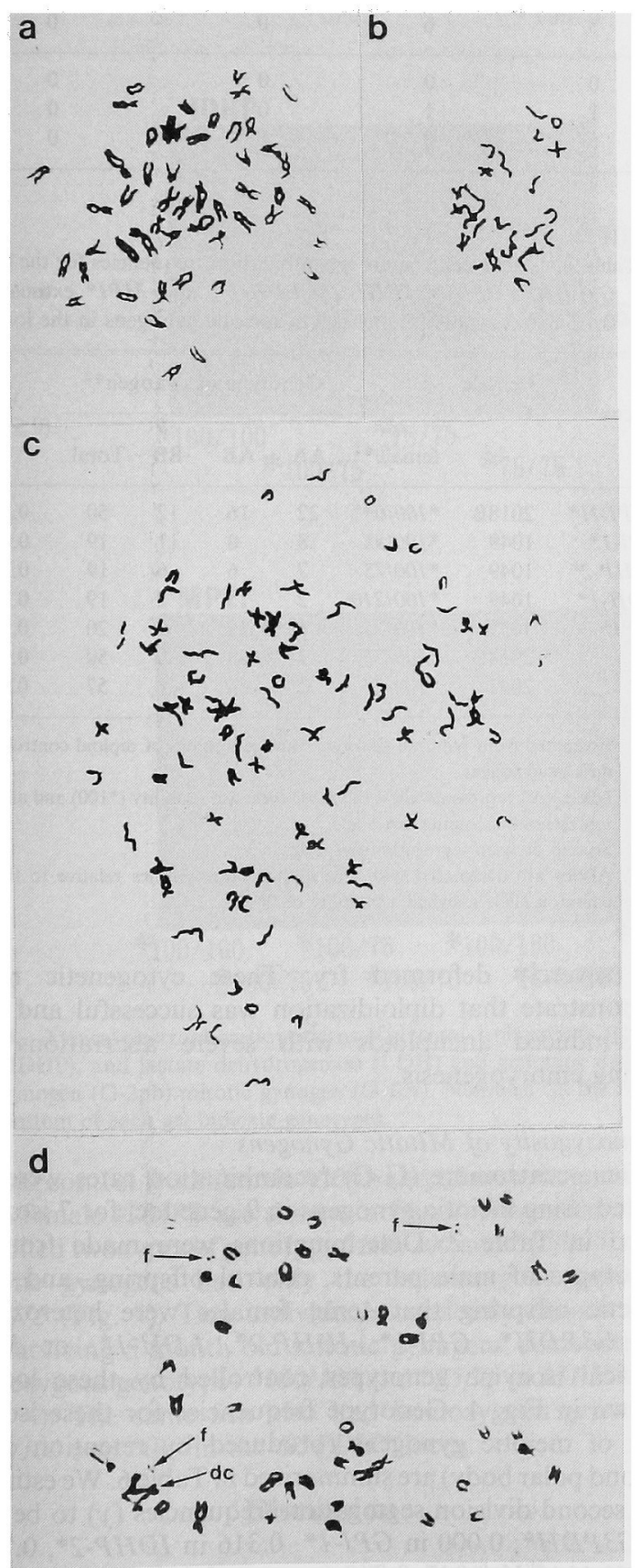

Fig. 2. Metaphase spreads of a) diploid $(2 n=50)$, b) haploid $(n=25)$, c) near tetraploid ( 85 chromosomes), and d) hypodiploid with chromosome fragments (f), and dicentromere (dc).
Chromosomes of Embryos and Fry from Eggs Subjected to Hydrostatic Pressure

Chromosomes of early embryos from eggs subjected to hydrostatic pressure were examined in the groups from females $¥ 2001,2018 \mathrm{~A}$, and 2019 at $10-18 \mathrm{~h}$ after fertilization (Table 4). All the embryos in the gynogenetic control (GC) possessed 25 chromosomes, the haploid number of a normal diploid loach, ${ }^{9)}$ which indicates successful induction of gynogenetic development (Fig. 2b). We observed diploid embryos in the experimental groups subjected to hydrostatic pressure treatment 25, 30, and $35 \mathrm{~min}$ after fertilization (Fig. 2a). Besides eudiploids with just 50 chromosomes,

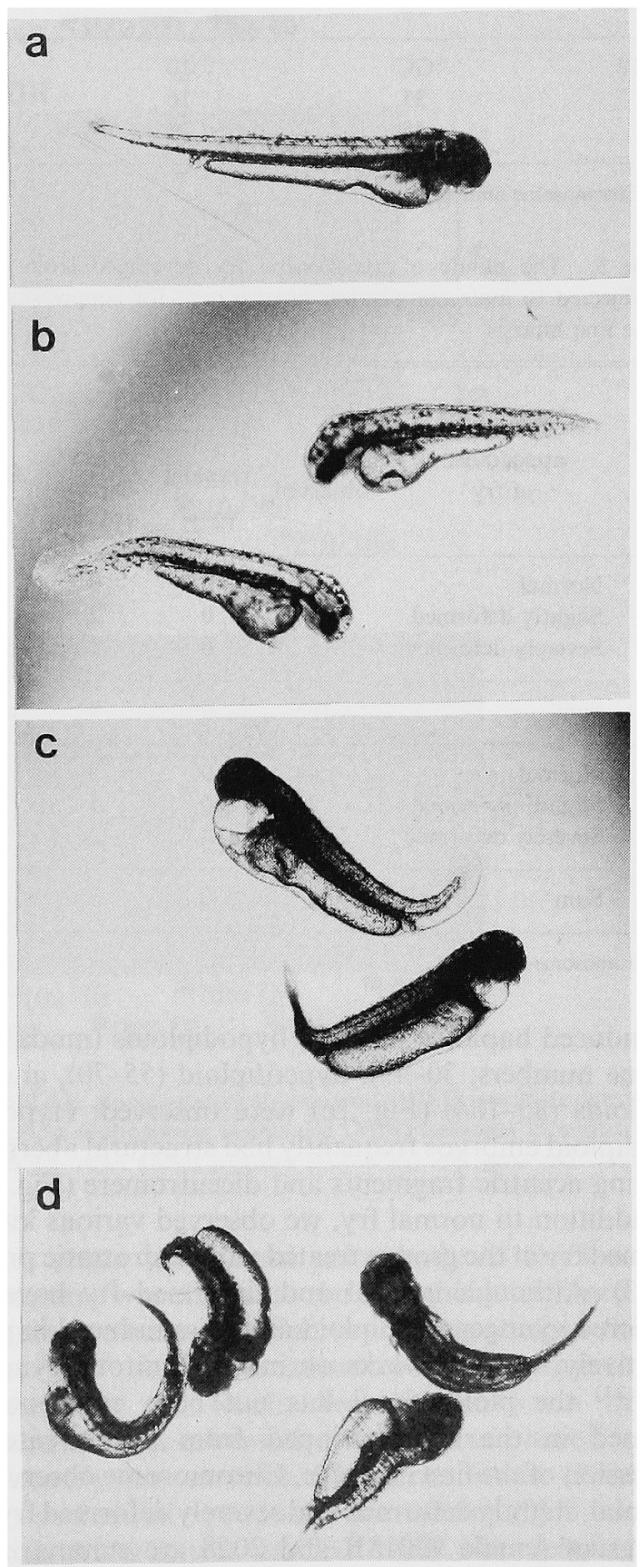

Fig. 3. External appearances of gynogenetic fry developed from eggs fertilized with irradiated spermatozoa: a) normal fry from eggs treated with hydrostatic pressure for suppression of the first cleavage; b) deformed fry with haploid syndrome in a gynogenetic control; c) slightly deformed fry from eggs treated with hydrostatic pressure for suppression of the first cleavage; d) severely deformed fry from eggs treated with hydrostatic pressure for suppression of the first cleavage. 
Table 4. The ploidy of developing embryos from eggs subjected to hydrostatic pressure at various starting times after fertilization

\begin{tabular}{|c|c|c|c|c|c|c|c|}
\hline \multirow{2}{*}{$\begin{array}{l}\text { Female } \\
\end{array}$} & \multirow{2}{*}{$\begin{array}{l}\text { Starting time } \\
\qquad(\mathrm{min})\end{array}$} & \multirow{2}{*}{$\begin{array}{l}\text { No. of embryos } \\
\text { observed }\end{array}$} & \multicolumn{5}{|c|}{ Ploidy status } \\
\hline & & & $\begin{array}{c}\text { Haploid } \\
(25)^{*}\end{array}$ & $\begin{array}{l}\text { Hypodiploid } \\
(30-49)\end{array}$ & $\begin{array}{l}\text { Diploid } \\
(50)\end{array}$ & $\begin{array}{l}\text { Hyperdiploid } \\
(55-70)\end{array}$ & $\begin{array}{l}\text { Near tetraploid } \\
(85-104)\end{array}$ \\
\hline \multirow[t]{4}{*}{2001} & $\mathrm{GC}$ & 12 & 12 & 0 & 0 & 0 & 0 \\
\hline & 25 & 31 & 24 & 0 & 7 & 0 & 0 \\
\hline & 30 & 20 & 1 & 3 & 6 & 2 & 8 \\
\hline & 35 & 26 & 10 & 3 & 7 & 5 & 1 \\
\hline \multirow[t]{3}{*}{$2018 \mathrm{~A}$} & $\mathrm{GC}$ & 10 & 10 & 0 & 0 & 0 & 0 \\
\hline & 30 & 12 & 3 & 3 & 5 & 1 & 0 \\
\hline & 35 & 12 & 3 & 3 & 6 & 0 & 0 \\
\hline \multirow[t]{3}{*}{2019} & GC & 10 & 10 & 0 & 0 & 0 & 0 \\
\hline & 35 & 16 & 14 & 1 & 1 & 0 & 0 \\
\hline & 45 & 20 & 14 & 5 & 0 & 1 & 0 \\
\hline
\end{tabular}

* Chromosome number.

Table 5. The ploidy of gynogenetic fry developed from eggs subjected to hydrostatic pressure treatment for suppression of the first mitosis

\begin{tabular}{|c|c|c|c|c|c|}
\hline \multirow[b]{2}{*}{$\begin{array}{l}\text { Female } \\
\text { \# }\end{array}$} & \multirow{2}{*}{$\begin{array}{c}\text { External } \\
\text { appearance } \\
\text { of fry }\end{array}$} & \multirow{2}{*}{$\begin{array}{c}\text { No. of } \\
\text { fry } \\
\text { observed }\end{array}$} & \multicolumn{3}{|c|}{ Ploidy status } \\
\hline & & & $\begin{array}{l}\text { Haploid } \\
(25)^{*}\end{array}$ & $\begin{array}{c}\text { Near } \\
\text { Diploid } \\
(40-49)\end{array}$ & $\begin{array}{c}\text { Diploid } \\
\text { (50) }\end{array}$ \\
\hline \multirow[t]{4}{*}{ 2018B } & Normal & 4 & 0 & 0 & 4 \\
\hline & Slightly deformed & 6 & 0 & 2 & 4 \\
\hline & Severely deformed & 6 & 0 & 1 & 5 \\
\hline & Sum & 16 & 0 & 3 & 13 \\
\hline \multirow[t]{4}{*}{2058} & Normal & 4 & 0 & 0 & 4 \\
\hline & Slightly deformed & 2 & 0 & 1 & 1 \\
\hline & Severely deformed & 5 & 0 & 2 & 3 \\
\hline & Sum & 11 & 0 & 3 & 8 \\
\hline
\end{tabular}

* Chromosome number.

miss-induced haploids ( $n=25$ ), hypodiploids (modal chromosome numbers; 30-49), hyperdiploid (55-70), and near tetraploids (85-104) (Fig. 2c) were observed. Hypo- and hyperdiploid embryos frequently had structural aberrations involving acentric fragments and dicentromere (Fig. 2d).

In addition to normal fry, we observed various kinds of deformed fry in the groups treated with hydrostatic pressure (Fig. 3). Although normal and deformed fry have been considered gynogenetic diploid and miss-induced haploids, respectively, in most works on induced mitotic gynogenesis, ${ }^{19-21)}$ the ploidy level has not been cytogenetically examined in the fry developed from eggs treated for suppression of the first cleavage. Chromosome observations of normal, slightly deformed and severely deformed fry from the eggs of female $\# 2018 \mathrm{~B}$ and 2058 are summarized in Table 5. All the normal fry developed from the treated eggs were confirmed as eudiploid with $2 n=50$ chromosomes. The deformed fry which survived were not haploid, but diploid $(2 n=50)$ or near diploid with modal chromosome numbers between 40 and 49 . Structural aberrations of chromosomes as observed in embryonic stages were not observed even in
Table 6. Gene-centromere recombination frequencies for the loci $G 3 P D H^{*}, G P I-1^{*}, I D H P-2^{*}, L D H-1^{*}$, and $M P I^{*}$ extimated from heterozygote frequencies of meiotic gynogens in the loach

\begin{tabular}{|c|c|c|c|c|c|c|c|}
\hline \multirow{2}{*}{ Locus } & \multirow{2}{*}{$\begin{array}{l}\text { Female } \\
\#\end{array}$} & \multirow{2}{*}{$\begin{array}{c}\text { Genotype } \\
\text { of } \\
\text { female*1 }^{* 1}\end{array}$} & \multicolumn{4}{|c|}{ Genotype of gynogen*2 } & \multirow{2}{*}{$\begin{array}{c}y^{* 3} \\
(0 \leqq y \leq 1)\end{array}$} \\
\hline & & & AA & $\mathrm{AB}$ & $\mathrm{BB}$ & Total & \\
\hline$G 3 P D H^{*}$ & $2018 \mathrm{~B}$ & $* 100 / 0^{* 4}$ & 22 & 16 & 12 & 50 & 0.320 \\
\hline$G P I-I^{*}$ & 1049 & $* 100 / 85$ & 8 & 0 & 11 & 19 & 0.000 \\
\hline$I D H P-2^{*}$ & 1049 & $* 100 / 75$ & 7 & 6 & 6 & 19 & 0.316 \\
\hline$L D H-I^{*}$ & 1049 & ${ }^{*} 100 / 210$ & 2 & 15 & 2 & 19 & 0.789 \\
\hline \multirow{3}{*}{$M P I^{*}$} & 1037 & $* 100 / 75$ & 1 & 19 & 0 & 20 & 0.950 \\
\hline & $2018 B$ & $* 100 / 75$ & 2 & 48 & 0 & 50 & 0.960 \\
\hline & 2041 & $* 100 / 75$ & 2 & 54 & 1 & 57 & 0.947 \\
\hline
\end{tabular}

*1 Estimated from paternal genotypes and genotypes of diploid control and/or meiotic gynogens.

*2 Allele "A" represents allele the most common mobility $\left({ }^{*} 100\right)$ and alleje "B" represents the counterpart allele.

*3 Second division segregation frequency.

*4 Alleles are designated with electrophoretic mobilities relative to the most common allele assigned a mobility of "* $100 "$ ".

the severely deformed fry. These cytogenetic results demonstrate that diploidization was successful and most miss-induced aneuploids with severe aberrations died during embryogenesis.

\section{Homozygosity of Mitotic Gynogens}

Gene-centromere $(\mathrm{G}-\mathrm{C})$ recombination rates were estimated using meiotic gynogens in 9 gene loci for 7 isozymes listed in Table 2. Determinations were made from the genotypes of male parents, control offspring, and gynogenetic offspring that some females were heterozygous for $G 3 P D H^{*}, G P I-1^{*}, I D H P-2^{*}, L D H-1^{*}$, or $M P I^{*}$. Typical isozyme genotypes controlled by these loci are shown in Fig. 4. Genotype frequencies for these isozyme loci of meiotic gynogens (produced by retention of the second polar body) are summarized in Table 6 . We estimated the second division segregation frequencies $(y)$ to be 0.320 in $G 3 P D H^{*}, 0.000$ in $G P I-1^{*}, 0.316$ in $I D H P-2^{*}, 0.789$ in $L D H-1^{*}$, and $0.947-0.960$ (average 0.952) in $M P I^{*}$ locus. Consequently, $M P I^{*}$ locus was selected as a marker gene because of its high $y$ value. MPI* genotypes of normal 

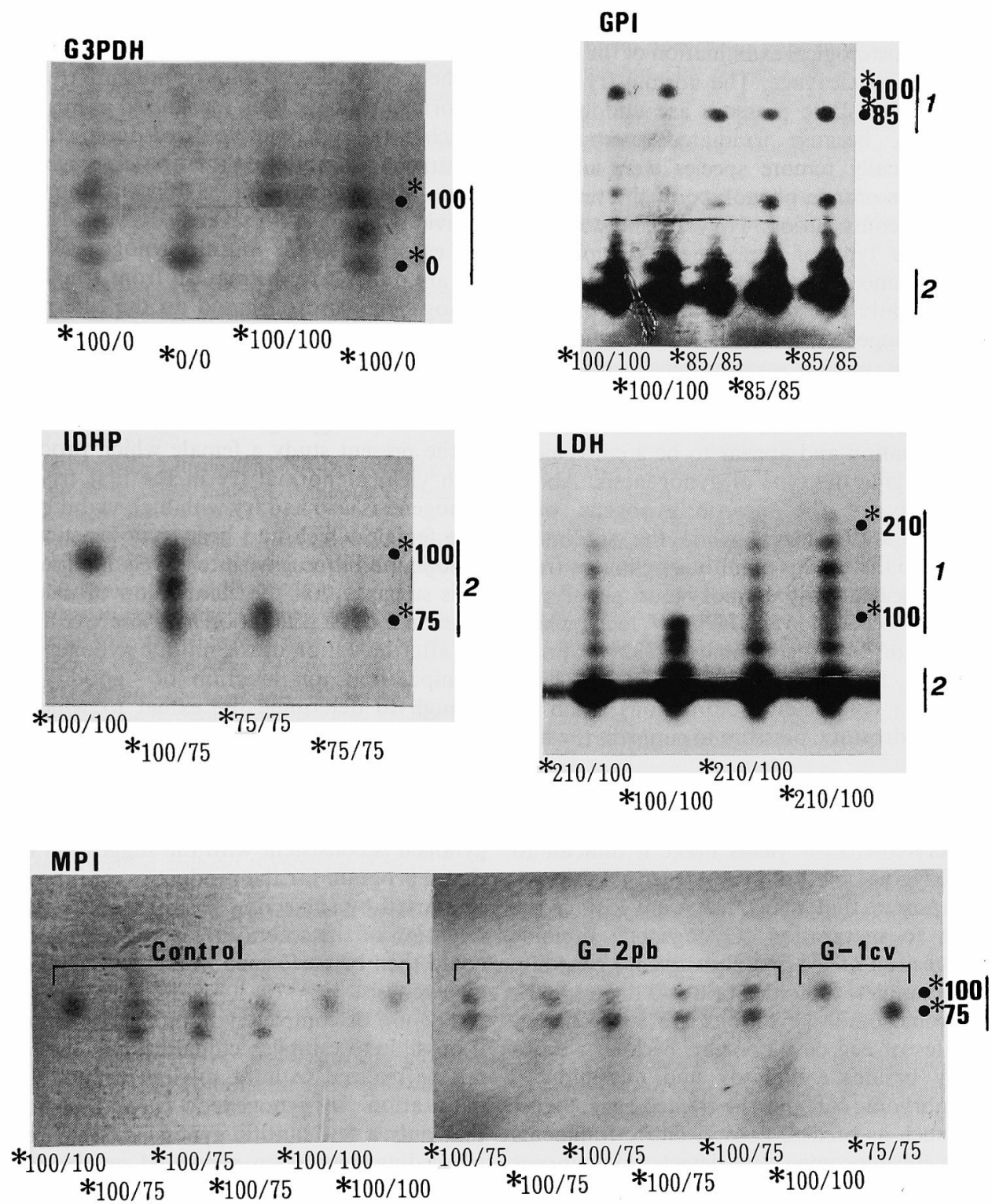

Fig. 4. Typical electrophoretic patterns of glycerol-3-phosphate dehydrogenase (G3PDH), glucosephosphate isomerase (GPI), isocitrate dehydrosenase (IDHP), and lactate dehydrogenase (LDH) and genotype distribution of mannose-6-phosphate isomeratse (MPI) isozymes in control, meiotic gynogen (G-2pb) mitotic gynogen (G-1cv). Numbers on the right side of each gel mean alleles (relative mobilities) and gene loci. Those at the bottom of each gel indicate genotypes.

diploid control from female $\# 2041$ and of meiotic gynogens from female $\# 2018 \mathrm{~B}$ are shown in Fig. 4. Normal diploids exhibited two types of genotype *100/100 and *100/75, while meiotic gynogens had only the heterozygous genotype *100/75 (Fig. 4). Two individuals randomly chosen from the surviving 5 month old mitotic gynogens demonstrated homozygous genotypes *100/100 and *75/75 in MPI* locus (Fig. 4). The same fish also had homozygous genotypes ${ }^{*} 100 / 100$ and ${ }^{*} 0 / 0$ in the $G 3 P D H^{*}$ locus.

\section{Discussion}

The highest yield of normal fry obtained by pressure treatment of 700 and $800 \mathrm{~kg} / \mathrm{cm}^{2}$ for $1 \mathrm{~min}$, starting $5 \mathrm{~min}$ after fertilization which was regarded as the appropriate time to retain the second polar body of the loach. The starting time was similar to the cold shock treatment. ${ }^{6)}$ The optimum pressure is similar to that reported in other fish species. $^{20-23)}$ A short treatment of 1 min seems to be the optimum for the loach, because the $6 \mathrm{~min}$ duration, recommended for salmonids, ${ }^{23)}$ ayu, ${ }^{8)}$ and plaice ${ }^{21)}$ resulted in extremely low survival. These conditions $\left(700 \mathrm{~kg} / \mathrm{cm}^{2}\right.$, $1 \mathrm{~min})$ successfully produced normal fry $(31.9-53.0 \%)$ in six trials when it was applied $5 \mathrm{~min}$ after fertilization to retain the second polar body for meiotic gynogenesis.

In contrast, proportions of developing embryos were very low when mitotic gynogenesis was done by suppressing the first cleavage. The most favorable survival producing normal fry were obtained in the groups treated 30 or $35 \mathrm{~min}$ after fertilization. This is similar to the effective time of 
application of heat-shock induction of gynogenetic carp, ${ }^{4}$ ) which was based on a histological examination of the timing of metaphase of the first cleavage. The normal fry which appeared after the hydrostatic pressure are undoubtedly gynogenetic products, because irradiated spermatozoa from the phylogenetically remote species were used to trigger development or orange phenotype of the resultant fry without paternal contribution. However, it was necessary to identify the type of gynogenesis, meiotic, or mitotic, because spontaneous retention of the second polar body has been frequently reported to occur and produce normal fry in the gynogenetic control. ${ }^{4,20,24)}$ To identify the type of gynogenesis, marker isozyme genes with nearly $100 \%$ gene-centromere (G-C) recombination rate were used. ${ }^{2,16,17,19,20,21,25)}$ In the loach, $M P I^{*}$ had a very high rate of G-C recombination and appear to be a convenient gene marker for verifying the type of gynogenesis. About $96 \%$ of the progeny of the meiotic gynogens were heterozygous at the $M P I^{*}$ locus, while the specimens randomly chosen from the groups of mitotic gynogens from the same female revealed only homozygous genotypes. Homozygosity was also detected in G3PDH* locus which had a moderate rate of $\mathrm{G}-\mathrm{C}$ recombination $(32 \%)$. From the results obtained here we conclude that we have successfully induced a completely homozygous loach by using the optimum hydrostatic pressure to suppress the first cleavage.

As discussed above, successful induction of mitotic gynogens was strongly suggested, but the yield of normal individuals was very low. Low yields make it difficult to maintain all homozygous fish until they reach adulthood. Komen et al. $^{4)}$ reported that many fish were lost in the course of rearing to maturation. Gynogenetic diploids produced by suppression of the first cleavage are generally unsuccessful. ${ }^{22)}$ Incomplete diploidization and the resultant occurrence of chromosome aberrations are suspected to cause very low rates of egg development, because we observed aneuploidy besides eudiploidy and miss-induced haploidy in the embryonic stage of the treated eggs. Structural aberrations such as breaks, gaps, acentric fragments and dicentromeric chromosomes were detected in embryos developed from eggs subjected to pressure 30,35 , and 40 min after fertilization, but no such severe aneuploidy was observed in the fry stage. These observations show that severe aneuploidy may mainly arrest development and results in subsequent mortality. Therefore, the harmful effect of the treatment on mitotic cell division may be largely responsible for the low rate in the successful induction of mitotic gynogenesis. Recently, Yamazaki and Goodier ${ }^{26}$ observed chromosome damage which affected viability of embryos treated with hydrostatic pressure at the first cleavage after normal fertilization in salmonids. They also concluded that abnormalities found in mitotic gynogens and tetraploids might result from the genetic imbalance precipitated by chromosome damage. Occurrence of chromosome aberrations and aneuploidy was also reported in tetraploidizing experiments of the bitterling. ${ }^{* 6}$

Our analysis of chromosomes in the fry stage demonstrated that the normal-looking fry examined were true diploids, while all the abnormal-looking fry were diploids or near-diploids rather than miss-induced haploidy in the groups subjected to the pressure treatment. Although deformed fry have been recognized as miss-inudced haploid which could not be diploidized due to the shortage of the treatment for inhibiting the first cleavage, ${ }^{20,21)}$ the present work demonstrates a significant number of diploid individuals even in the severely deformed fry developed from the eggs treated for mitotic gynogenesis. These deformed fry are difficult to distinguish from true haploid fry in the gynogenetic control, based on the external appearance of the fry. Some of the low survival of the mitotic gynogens may result from homozygosity. The role of the genetic background specific to each female on the success or failure of the mitotic gynogenesis should be investigated, because in the present study a female which produced a relatively high yield of normal fry in the first trial for the mitotic gynogenesis also had fry with high viability in the next trial. The female which had been gynogenetically produced by meiotic inhibition gave a relatively high viability of the fry. This suggests that the elimination of deleterious recessive genes in the first generation may improve the yield of normal fry after induction of the mitotic gynogenesis. This kind of manipulation for selection of "good" females may be enough to determine the extent to which deleterious lethal genes exist. According to Allendrof and Leary, ${ }^{27)}$ gynogenetic fish induced by blocking meiosis will be partially inbred and are inbred equivalent to two or three generations of full-sibmating. The improved yield of mitotic gynogen is consistent with the suggestion by Chourrout ${ }^{22)}$ that a program for the production of inbred strains should be started by subjecting several females to gynogenesis by retention of the second polar body. Fixation of the strain could then be performed in the next generation by mitotic gynogenesis.

The use of completely homozygous gynogens will make it possible to establish clonal lines in the loach, but it will not be realized without solving problems of survival and maturation. In gynogenetic carp, Komen et al. ${ }^{4}$ found that only a few mitotic gynogens could reproduce due to inbreeding depression expressed on the gonadal development. The same observation has been made on the reduced fertility of mitotic gynogens in salmonids.*7 However, clonal production has been realized in several fish species including commercially important carp, ${ }^{4)}$ ayu, ${ }^{5)}$ and plaice. ${ }^{6}$ The high fecundity of fish including the loach may be the only means to overcome difficulties encountered during the first generation of mitotic gynogens and thus the effects of inbreeding depression on survival and reproduction.

Acknowledgments We wish to express our gratitude to Prof. Anthony J. Gharrett, Juneau Center School of Fisheries and Ocean Sciences, University of Alasks Fairbanks, for his interesting discussion and critical reading of our manuscript. We are also very grateful to Mr. Tetsuji Masaoka and Miss Kumi Matsubara, Graduate School of Biosphere Sciences, Hiroshima University for their technical assistance on fertilization, manipulation and rearing. This work was supported in part by a Grant-in-Aid for Scientific Research (No. 02454080) from the Ministry of Education, Science, and Culture of Japan to R. S.

*6 T. Ueda and S. Aoki; Abst. Meetg. Japan. Soc. Sci. Fish., April, 1993, p. 191 (in Japanese).

*7 H. Onozato: Yoshokuken nyusu, no. 21, pp. 9-16, National Institute of Aquaculture, Nansei, Mie (1991) (in Japanese). 


\section{References}

1) Y. Hyodo-Taguchi and N. Egami: Establishment of inbred strains of the medaka Oryzias latipes and the usefulness of the strains for biomedical research. Zool. Sci., 2, 305-316 (1985).

2) G. Streisinger, C. Walker, N. Dower, D. Knauber, and F. Singer: Production of clones of homozygous diploid zebra fish, (Brachydanio rerio). Nature, 291, 293-296 (1981).

3) K. Naruse, K. Ijiri, A. Shima, and N. Egami: The production of cloned fish in the medaka (Oryzias latipes). J. Exp. Zool, 236, 335341 (1985).

4) J. Komen, A. B. J. Bongers, C. J. J. Richter, W. B. Van Muiswinkel and E. A. Huisman: Gynogenesis in common carp (Cyprinus carpio L.). II. The production of homozygous gynogenetic clones and F1 hybrids. Aquaculture, 92, 127-142 (1991).

5) H.S. Han, H. Mannen, A. Tsujimura, and N. Taniguchi: Application of DNA fingerprinting to confirmation of clone in ayu. Nippon Suisan Gakkaishi, 58, 2027-2031 (1992).

6) M. Hara, K. Dewa, and E. Yamamoto: DNA-fingerprinting with non-radioactive probe in clonal flounder Paralichthys olivaceus Nippon Suisan Gakkaishi, 59, 731 (1993).

7) R. Suzuki, T. Oshiro, and T. Nakanishi: Survival, growth and fertility of gynogenetic diploids induced in the cyprinid loach, Misgurnus anguillicaudatus. Aquaculture, 48, 45-55 (1985).

8) R. Suzuki: Hybridization experiments in cyprinid fishes. XI. Survival rate of $F 1$ hybrids with special reference to the closeness of taxonomical position of combined fishes. Bull. Freshwater Fish. Res. Lab., 18, 113-155 (1968).

9) K. Arai, K. Matsubara, and R. Suzuki: Chromosomes and developmental potential of progeny of spontaneous tetraploid loach Misgurnus anguillicaudatus. Nippon Suisan Gakkaishi, 57, 2173-2178 (1991).

10) Y. Ojima, A. Takai, and K. Yamamoto: Production and chromosomal features of triploid hybrids between Rhodeus ocellatus ocellatus and Acheilognathus zimbatus (Cyprinidae, Pisces). Proc Japan Acad., 64B, 225-228 (1988).

11) J. W. Clayton and D. N. Tretiak: Aminocitrate buffer for $\mathrm{pH}$ control of starch gel electrophoresis. J. Fish. Res. Bd. Can. 29, 11691172 (1972).

12) G. J. Ridgway, S. W. Sherberne, and R. D. Lewis: Polymorphisms in the serum esterases of Atlantic herring. Trans. Am. Fish. Soc, 99, 147-151 (1970)

13) J. B. Shaklee, F. W. Allendorf, D. C. Morizot, and G. S. Whitt Gene nomenclature for protein coding loci in fish. Trans. Am. Fish. Soc., 119, 2-15 (1990).
14) F. W. Allendorf, N. Mitchell, N. Ryman, and G. Stahl: Isozyme loci in brown trout (Salmo trutta L.): detection and interpretation from population data. Hereditas, 86, 179-190 (1977).

15) P. B. Aebersold, G. A. Winans, D. J. Teel, G. B. Milner, and F. M Utter: Manual for starch gel electrophoresis: A method for the detection of genetic variation. NOAA Technical Report NMFS, 61, 1-19 (1987).

16) G. H. Thorgaard, F. W. Allendorf, and K. L. Knudsen: Gene-centromere mapping in rainbow trout: High interference over long map distances. Genetics, 103, 771-783 (1983).

17) F. W. Allendorf, J. E. Seeb, K. L. Knudsen, G. H. Thorgaard, and R. F. Leary: Gene-centromere mapping of 25 loci in rainbow trout. J. Heredity, 77, 307-312 (1986).

18) K. Naruse and A. Shima: Linkage relationships of gene loci in the medaka, Oryzias latipes (Pisces: Oryziutidae), determined by backcrosses and gynogenesis. Biochem. Genet., 27, 183-198 (1989).

19) N. Taniguchi, A. Kijima, and J. Fukai: High heterozygosity at Gpi-1 in gynogenetic diploids and triploids of ayu Plecoglossus altivelis. Nippon Suisan Gakkaishi, 53, 717-720 (1987)

20) N. Tanigushi, S. Seki, J. Fukai, and A. Kijima: Induction of two types of gynogenetic diploids by hydrostatic pressure shock and verification by genetic marker in ayu. Nippon Suisan Gakkaishi, 54, 1483-1491 (1988).

21) K. Tabata and S. Gorie: Induction of gynogenetic diploids in Paralichthys olivaceus by suppression of the 1st cleavage with special reference to their survival and growth. Nippon Suisan Gakkaishi, 54, 1867-1872 (1988) (in Japanese).

22) D. Chourrout: Pressure-induced retention of second polar body and suppression of first cleavage in rainbow trout: production of all-triploids, all-tetraploids, and heterozygous and homozygous diploid gynogenesis. Aquaculture, 36, 111-126 (1984).

23) H. Onozato: Diploidization of gynogenetically activated salmonid eggs using hydrostatic pressure. Aquaculture, 43, 91-97 (1984).

24) C. E. Purdom, K. Thompson, and Y. D. Lou: Genetic engineering in rainbow trout, Salmo gairdneri $\mathrm{R}$., by suppression of meiotic and mitotic metaphase. J. Fish Biol., 27, 73-79 (1985).

25) R. Guyomard: High level of residual heterozygosity in gynogenetic rainbow trout, Salmo gairdneri Richardson. Theor. Appl. Genet., 67, 307-316 (1984).

26) F. Yamazaki and J. Goodier: Cytogenetic effects of hydrostatic pressure treatment to suppress the first cleavage of slamon embryos. Aquaculture, 110, 51-59 (1993)

27) F. W. Allendorf and R. F. Leary: Heterozygosity in gynogenetic diploids and triploids estimated by gene-centromere recombination rates. Aquaculture, 43, 413420 (1984). 